\title{
THE IMPACT OF LENDING TO NON-FINANCIAL CORPORATIONS ON ECONOMIC GROWTH
}

\author{
Rogneda Vasilyeva ${ }^{1}$, Oleg Turygin ${ }^{2}$, Olga Ie $^{3}$, Maria Kozlova $^{4}$
}

\begin{abstract}
Acceleration of economic growth, especially in modern conditions, requires the use of stimulating measures of fiscal and monetary policy. Measures to stimulate economic growth should also maintain macroeconomic stability. Many emerging markets and developing economies are pursuing high interest rate policies to curb inflation, but this leads to a reduction in lending to non-financial corporations and to economic growth rates decline. The goal of the study is to show that pursuing high interest rates policy is insufficient. We tested several hypotheses: first, we assume that an increase in lending to non-financial corporations stimulates economic growth. Our second hypothesis, in contrast, suggests that increasing interest rates on loans dampen economic growth. Third, we assume that inflation has no significant effect on economic growth. Forth, we consider that lending to non-financial corporations does not spur inflation. We empirically assess the data for 13 countries related to emerging markets during 2001-2020. The results of the research confirmed all the hypotheses. The monetary policy of maintaining high interest rates used by many developing countries leads to low lending to non-financial corporations and reduced economic growth. We propose several policy implications aimed at stimulating the lending to non-financial corporations and scarce inflation.
\end{abstract}

JEL Classification Numbers: E22, E52, F43, DOI: 10.12955/peb.v2.262

Keywords: lending, non-financial corporations, economic growth, inflation

\section{Introduction}

Accelerating economic growth is a major challenge for modern markets. Developed countries use monetary instruments extensively to boost economic growth, such as keeping interest rates on loans at a low level (close to zero). However, most countries related to emerging markets and developing economies adhere to high interest rate policies, which are justified by the goal of reducing inflation. There is a need to study the impact of interest rates and lending to non-financial companies on economic growth in this situation. The purpose of the study is to show that the policy of high interest rates is insufficient for developing economies. For this purpose, we tested four hypotheses. First, we believe that an increase in lending to non-financial corporations stimulates economic growth. Second, we suggest that increasing interest rates on loans harm the economic growth rates. The third hypothesis suggests that inflation has no significant effect on economic growth. And last, we consider that lending to non-financial corporations does not spur inflation. To test the stated assumptions, we imply an econometric approach for panel data estimation. We empirically assess the data for 13 emerging and developing economies for the period 2001-2020. The estimation results show that the pursued monetary policy aimed at maintaining high interest rates, which is common for most emerging and developing countries, reduces the lending to non-financial corporations and results in the stagnation of the economic growth. Therefore, we propose several policy implications to stimulate lending to non-financial corporations and decrease the inflation.

\section{Literature review}

During the modern crisis provoked by the new coronavirus disease, the governments of all countries imposed additional monetary policies aimed at economic stimulation and espousal of individuals and enterprises. However, to gain sustainable and efficient results of such policies, the long-term consequences must be considered. The world crisis of 2007-2009 resulted in the rising costs due to manufacturing decline and decrease of GDP, which amounted to the billion dollars (Martin, F., 2013). The previous crises, in particular the long recession, which occurred after 1973 due to the stagnating fixed capital growth rates, restrained the capital formation growth and resulted in economic stagnation. The constraint of the economic growth increased economic instability. The decreasing government regulation of the financial sector after 1980 provoked new financial crises. Liberalization of the capital

\footnotetext{
${ }^{1}$ Graduate School of Economics and Management, Ural Federal University, Ekaterinburg, Russian Federation, rogneda.groznykh@urfu.ru

${ }^{2}$ Graduate School of Economics and Management, Ural Federal University, Ekaterinburg, Russian Federation, turigin@mail.ru

${ }^{3}$ Graduate School of Economics and Management, Ural Federal University, Ekaterinburg, Russian Federation, olgaie@mail.ru

${ }^{4}$ Graduate School of Economics and Management, Ural Federal University, Ekaterinburg, Russian Federation, kozlova_mary@mail.ru
} 
markets in the countries with previous capitalist system extended the countries with emerging markets. Long recession continued in the first years of the 21st century due to steady overproduction in the industrial sector and the slowing-down growth of cumulative demand (investment, state and consumer). Friedman M. (1956) noted that according to the theory of money demand, "the credit lever" is considered, i.e. it is supposed that liabilities of firm entirely balanced by its assets. According to Friedman, inflation results from the more rapid growth of the money supply in comparison with the output. The monetary nature of inflation is a generalization of all other factors; therefore, the only effective way to stop inflation is to restrict money supply growth rates. The policy of the central banks of the majority of the emerging markets relies on the monetary theory. In the modern practice of monetary regulation, the central banks passed from regulation of money circulation to inflation targeting. The main instrument of the inflation rate reduction is the restriction of money supply reached by crediting restriction, including crediting of the industrial enterprises.

The analysis of Studwell (2013) shows the successful example of Northeast Asian countries, which confirms that it is not necessary to resort to liberalization and deregulation of the financial markets at early stages of economic development. Banks can use financial resources not for investments in production but for financial speculation. The state policy of supporting "the young industry" required bank loans to the manufacturing industry, which are not associated with immediate profit. In addition, the inflow and outflow of the international capital were restricted to foreign investments that would not harm the development of the priority industries.

Reinert (2007) highlights that arrangement of the mechanized production and extension of the industrial production accounts for the reduction of the specific marginal costs, which do not grow (as in agricultural production), i.e. there is a growth of the economy from production scale. Therefore, the growth of investments into production activity is a necessary condition to increase social wealth. The sovereign state has monopoly for creating money; however, de facto, government transfers that monopoly to the hands of private agents. The state charges to the Central bank, which formally is independent on the government in most developed and developing countries. The Central bank provides an opportunity for private banks to create credit money. Calomiris C. \& Haber, S. (2014) argues that when the system of credit money realized by private banks becomes less stable, the central bank resorts to exclusive measures to rescue the banks in financial difficulties. For that purpose Central bank provides emergency liquidity ("discount window"), purchase of bad debts ("problem assets"), which taxpayers finance. Brenner, R. (2006), Reinhart, C. \& Rogoff, K. (2011) evidence that financial and economic crises are an inevitable result of liberalization of the financial markets. Consequences of crises are assigned to society while profit is appropriated in a private order (Gamble, A., 2014).

Korkmaz, S. (2015) investigated the internal credits created by the banking sector and their impact on inflation and economic growth. The research was provided for ten European countries for the period 2006-2012, implementing panel data analysis. The results confirm that the higher level of penetration of financial services is significant for the direction of the means created by banks to the real sector. Coincidently, the internal credits created by the banking sector has no significant effect on inflation, while it influences economic growth. Muhammad, I. (2016) argues that the excess crediting can lead to an increase in non-performing loans, which in its turn will negatively affect economic growth. Muntean, R. (2015) concludes that in the context of the financial crisis, the impact of lending on economic growth is significantly lower, while bank lending gets benefits from developments of the local economy. Chang H. J. (2008), in his research, states that too tough a monetary policy leads to a decrease in investment. Thus, regulation of a banking system for the purpose of priority crediting of the non-financial companies will allow spurring economic growth and lower losses from speculative financial investment.

\section{Data and methodology}

In the study, we use variables characterizing the lending and economic growth level for 2001-2020. The variables description is represented in Table 1 . The sample includes countries that belong to emerging markets and developing economies, according to the IMF classification.

Our dataset contains yearly data on Argentina, Brazil, Chile, China, Colombia, Hungary, India, Indonesia, Mexico, Malaysia, Russia, South Africa, and Thailand. Poland, Saudi Arabia, and Turkey are not included in the sample, since no data on lending interest rates is available for the mentioned countries. The descriptive statistics is represented in Table 2. 


\begin{tabular}{|l|l|l|}
\hline \multicolumn{2}{|l|}{ Table 1: Variable Description and Sources data } \\
\hline Variable & Description & data Source \\
\hline GDPGrowth & $\begin{array}{l}\text { The annual percentage growth rate of GDP at market } \\
\text { prices based on constant local currency. }\end{array}$ & $\begin{array}{l}\text { the World Bank } \\
\text { https://www.worldbank.org }\end{array}$ \\
\hline credNFC & $\begin{array}{l}\text { Credit to non-financial corporations from all sectors at } \\
\text { market value - Percentage of GDP - Adjusted for breaks }\end{array}$ & $\begin{array}{l}\text { Bank for International Settlements } \\
\text { https://www.bis.org }\end{array}$ \\
\hline lendIR & $\begin{array}{l}\text { Lending interest rate (\%) - Lending rate is the bank rate } \\
\text { that usually meets the short- and medium-term financing } \\
\text { needs of the private sector }\end{array}$ & $\begin{array}{l}\text { the World Bank } \\
\text { https://www.worldbank.org }\end{array}$ \\
\hline defGDP & GDP deflator (annual \%) & $\begin{array}{l}\text { the World Bank } \\
\text { https://www.worldbank.org }\end{array}$ \\
\hline Source: authors
\end{tabular}

\begin{tabular}{|l|l|l|l|l|l|}
\hline \multicolumn{5}{|l}{ Table 2: Descriptive statistics of variables } \\
\hline Variable & Obs N $(\mathrm{n} ; \mathrm{T})$ & Mean & Std. Dev. & Min & Max \\
\hline GDPGrowth & $247(13 ; 19)$ & 4.01 & 3.40 & -10.89 & 14.23 \\
\hline credNFC & $236(13 ; 18.15)$ & 51.35 & 31.95 & 11.4 & 160.7 \\
\hline lendIR & $248(13 ; 19.08)$ & 10.64 & 12.46 & 0.12 & 67.25 \\
\hline defGDP & $260(13 ; 20)$ & 6.95 & 7.27 & -5.99 & 50.62 \\
\hline
\end{tabular}

Note: Obs $\mathrm{N}$ - the total number of observations, $\mathrm{n}$ - number of objects, $\mathrm{T}$ - average number of observations for objects, Mean - mean value of the variable, Std. Dev. — standard deviation, Min — minimum value, Max - maximum value.

Source: Authors

For our estimation, we use panel data. We performed tests of Westerlund (2005) on the possibility of combining data into a panel. Tests have a null hypothesis of no cointegration, and the alternative hypothesis of the tests is that the variables are cointegrated in all panels. The results of the test are represented in Table 3.

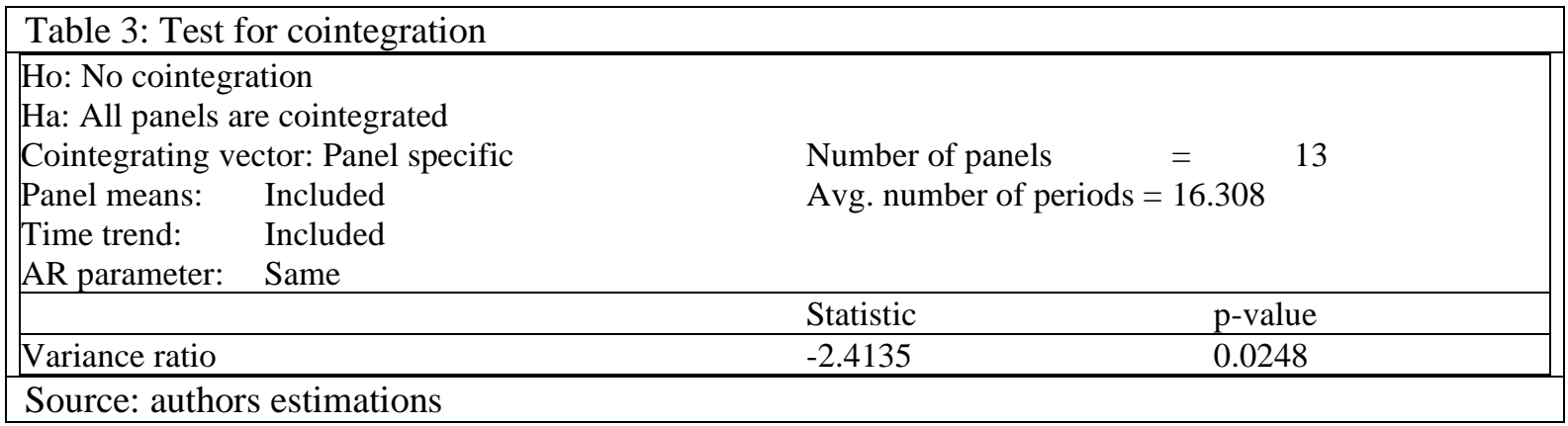

The hypothesis of no integration is rejected at $1 \%$ significance level; therefore the data can be combined into a panel. Next, we implement the Wooldridge test (Wooldridge, 2002). Table 4 represents estimation results for the test.

Table 4. Test for autocorrelation in panel data

\begin{tabular}{|l|l|l|}
\hline & $\begin{array}{c}\text { H0: no first-order autocorrelation } \\
\mathrm{F}(1, \quad 12)=2.639 \\
\text { Prob }>\mathrm{F}=0.1302\end{array}$ & \\
\hline Source: authors estimations
\end{tabular}

We rejected the hypothesis of no first-order autocorrelation at $10 \%$ significance level, thus autocorrelation is present. According to the heteroscedasticity test (Table 5), we reject the hypothesis of homoscedasticity at $10 \%$ significance level; thus the data has heteroskedasticity.

\begin{tabular}{|l|l|}
\hline Table 5. Test for homoscedasticity & \\
\hline & $\begin{array}{l}\text { H0: homoscedasticity } \\
\text { Ha: unrestricted heteroskedasticity } \\
\text { chi2(9) }=13.80 \\
\text { Prob }>\text { chi2 }=0.1297\end{array}$ \\
\hline Source: authors estimations \\
\hline
\end{tabular}


In the case of autocorrelation of random components and heteroscedasticity, Generalized least squares (GLS) can be used instead of the ordinary least squares (OLS) method to evaluate dependencies between variables. To assess the impact of loans to non-financial corporations, we form the following econometric model:

GDPGrowth $_{\text {it }}=\mathrm{a}+\mathrm{b}_{1} \times$ credNFC $_{i t}+\mathrm{b}_{2} \times$ lendIR $_{i t}+\mathrm{b}_{3} \times \operatorname{defGDP}_{i t}+\varepsilon_{\mathrm{it}}(2)$,

where GDPGrowth it $_{-}$is gross domestic product growth rate, credNFC $_{i t}$ - loans to non-financial corporations, lendIR $i t$ - lending interest rate, $\operatorname{defGDP}_{i t}-$ GDP deflator, $\varepsilon_{i t}-$ error term.

\section{Results and Discussion}

Based on equation 2 we test the hypothesis stated above. For achieved unbiased estimations, we check for the multicollinearity implementing correlation matrix (Table 6), which shows that the correlation coefficients between variables do not exceed 0.5 , indicating that there is no strong correlation between variables and variance inflation factor (Table 7).

\begin{tabular}{|l|l|l|l|l|}
\hline \multicolumn{5}{|l|}{ Table 6: Correlation matrix } \\
\hline & GDPGrowth & credNFC & lendIR & defGDP \\
\hline GDPgrowth & 1.0000 & & & \\
\hline credNFC & 0.2242 & 1.0000 & & \\
\hline lendIR & -0.2834 & -0.2507 & 1.0000 & \\
\hline defGDP & -0.1070 & -0.3681 & 0.4101 & 1.0000 \\
\hline
\end{tabular}

Source: authors estimations

No variable has a VIF value greater than 3, the hypothesis of the presence of multicollinearity is rejected.

\begin{tabular}{|l|l|l|l|}
\hline Table 7: Variance inflation factor \\
\hline & Variable & VIF & $1 /$ VIF \\
\cline { 2 - 4 } & defGDP & 1.32 & 0.756709 \\
& lendIR & 1.22 & 0.820284 \\
& credNFC & 1.17 & 0.852582 \\
\cline { 2 - 4 } & Mean VIF & 1.24 & \\
\hline Source: authors estimations
\end{tabular}

The regression results are represented in Table 8.

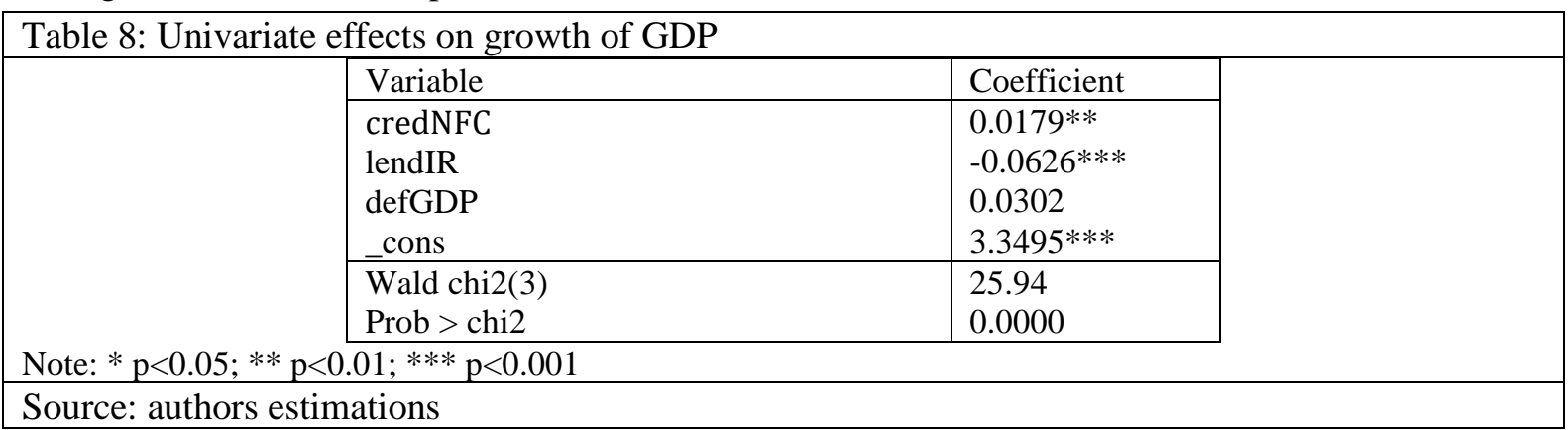

Based on the results of econometric modelling, we conclude that credit to non-financial corporations has a significant and positive impact on economic growth, lending interest rate has a significant and negative impact on the economic growth, and the overall level of inflation is measured as GDP deflator does not have a significant impact on economic growth.

In order to test the fourth hypothesis, we create an econometric model (3):

$\operatorname{defGDP}_{i t}=\mathrm{a}+\mathrm{b} \times \operatorname{credNFC}_{i t}+\varepsilon_{\text {it }}(3)$,

where defGDP $i t-$ GDP deflator, credNFC $i t-$ loans to non-financial corporations, $\varepsilon_{i t}-$ error term.

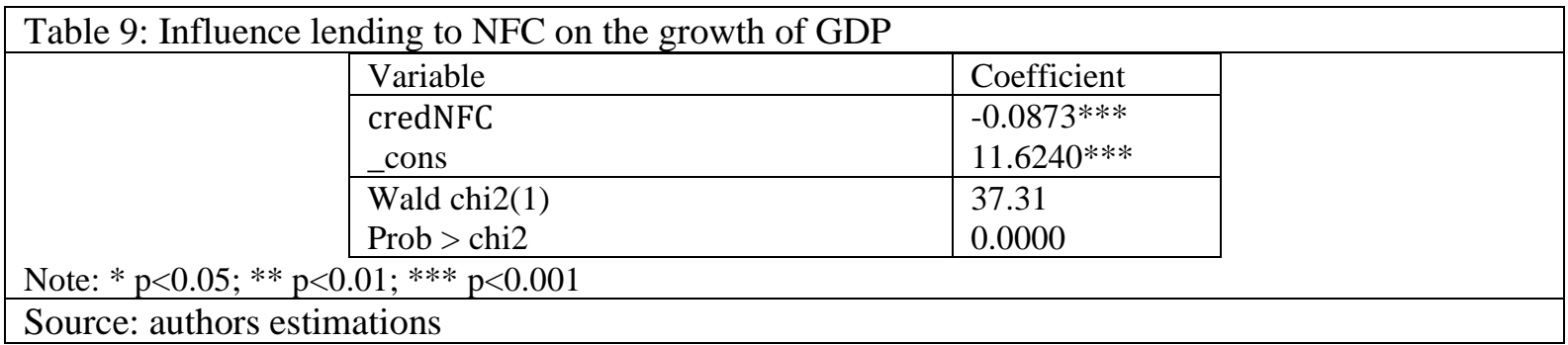


The results of the model estimations are represented in Table 9.

Increased lending to non-financial corporations has a negative impact on inflation. An increase in lending to non-financial corporations leads to an increase in investment in production equipment and an increase in output. Increasing the supply of products while maintaining demand at a constant level leads to lower prices and lower inflation.

\section{Conclusion}

The results of the study confirm the main hypothesis that the level of lending to non-financial corporations has a positive impact on the level of economic growth. The policy of stimulating lending to the non-financial sector is the basis for long-term economic development. However, in the emerging market and developing economies, including Russia, the level of lending to non-financial corporations is at a low level. The reason is the pursued policy of central banks, aimed at the lending limitation. The ratio of short-term and long-term goals of financial (monetary and fiscal) policy determines the set of measures implemented by the monetary regulatory authorities. Currently, the prevailing view in most emerging markets and developing economies is that monetary authorities are only responsible for creating the necessary conditions, primarily for financial stability, and other government authorities should be responsible for economic growth. Therefore, the task of economic growth is not even set before the monetary authorities of those countries. Although in the United States, the priorities are equally important to maintain a high level of employment, which is possible with sustained economic growth and macroeconomic stability, manifested primarily in a low level of inflation.

To summarize, we confirm that for the monetary authorities of emerging markets and developing economies, the priority should be to increase the level of lending to the non-financial corporations and not to maintain a low level of lending to achieve the secondary goal of achieving a low level of consumer inflation.

\section{Acknowledgements}

The study was supported by the RFBR grant 20-010-00724 "Assessment and forecast of transport accessibility and security of the regions of the Russian Federation and their impact on the indicators of sustainable spatial development".

\section{References}

Brenner, R. (2006). The economics of global turbulence: the advanced capitalist economies from long boom to long downturn, 1945-2005. Verso, 369.

Calomiris, C. \& Haber, S. (2014). Fragile by design: the political origins of banking crises and scarce credit. Princeton University Press

Chang, H. J. (2008). Bad samaritans: the myth of free trade and the secret history of capitalism. Bloomsbury Press.

Friedman, M. (1956) The Quantity Theory of Money—A Restatement. In: Friedman, M., Ed., Studies in the Quantity Theory of Money. University of Chicago Press, Chicago, 1-21

Gamble, A. (2014) Crisis Without End?: The Unravelling of Western Prosperity. Palgrave Macmillan, 240.

Korkmaz, S. (2015). Impact of bank credits on economic growth and inflation. Journal of Applied Finance \& Banking. 5. 57 69.

Martin, F. (2013). Money, the unauthorised biography. Bodley Head.

Muhammad, I.A. et al. (2016). Non-Performing Loans and Economic Growth. Scholars journal of economics, business and management. 3(10). 584-586

Muntean, R. (2015). Foreign Support, Local Lending and Economic Growth. Procedia Economics and Finance 32. 566 - 573

Reinhart, C. \& Rogoff, K. (2011). This time is different: eight centuries of financial folly Princeton, University Press, 463.

Reinert, E.S. (2007). How rich countries got rich and why poor countries stay poor. London: Constable \& Robinson.

Studwell, J. (2013). How Asia works: success and failure in the world's most dynamic region. Grove Press.

Westerlund, J. (2005). New simple tests for panel cointegration. Econometric Reviews 24: 297-316.

Wooldridge, J. M. (2002). Econometric Analysis of Cross Section and Panel Data. Cambridge, MA: MIT Press. 